\title{
Review \\ Human Umbilical Cord: Information Mine in Sex-Specific Medicine
}

\author{
Ilaria Campesi ${ }^{1, *(\mathbb{C}}$, Flavia Franconi ${ }^{2}$, Andrea Montella ${ }^{1,3} \mathbb{C}$, Salvatore Dessole ${ }^{4}$ and Giampiero Capobianco ${ }^{4}$ \\ 1 Dipartimento di Scienze Biomediche, Università degli Studi di Sassari, 07100 Sassari, Italy; montella@uniss.it \\ 2 Laboratorio Nazionale sulla Farmacologia e Medicina di Genere, Istituto Nazionale Biostrutture Biosistemi, \\ 07100 Sassari, Italy; franconi.flavia@gmail.com \\ 3 Unità Operativa di Genetica e Biologia dello Sviluppo, Azienda Ospedaliero Universitaria di Sassari, \\ 07100 Sassari, Italy \\ 4 Dipartimento di Scienze Mediche, Chirurgiche e Sperimentali, Clinica Ostetrica e Ginecologica, \\ Università degli Studi di Sassari, 07100 Sassari, Italy; dessole@uniss.it (S.D.); capobia@uniss.it (G.C.) \\ * Correspondence: icampesi@uniss.it; Tel.: +39-079-228-518
}

check for updates

Citation: Campesi, I.; Franconi, F.;

Montella, A.; Dessole, S.; Capobianco,

G. Human Umbilical Cord:

Information Mine in Sex-Specific

Medicine. Life 2021, 11, 52.

https://doi.org/10.3390/life11010052

Received: 6 November 2020

Accepted: 12 January 2021

Published: 13 January 2021

Publisher's Note: MDPI stays neutral with regard to jurisdictional clai$\mathrm{ms}$ in published maps and institutional affiliations.

Copyright: $\odot 2021$ by the authors. Licensee MDPI, Basel, Switzerland. This article is an open access article distributed under the terms and conditions of the Creative Commons Attribution (CC BY) license (https:// creativecommons.org/licenses/by/ $4.0 /)$.

\begin{abstract}
Biological differences between sexes should be considered in all stages of research, as sexual dimorphism starts in utero leading to sex-specific fetal programming. In numerous biomedical fields, there is still a lack of stratification by sex despite primary cultured cells retaining memory of the sex and of the donor. The sex of donors in biological research must be known because variations in cells and cellular components can be used as endpoints, biomarkers and/or targets of pharmacological studies. This selective review focuses on the current findings regarding sex differences observed in the umbilical cord, a widely used source of research samples, both in the blood and in the circulating cells, as well as in the different cellular models obtainable from it. Moreover, an overview on sex differences in fetal programming is reported. As it emerges that the sex variable is still often forgotten in experimental models, we suggest that it should be mandatory to adopt sex-oriented research, because only awareness of these issues can lead to innovative research.
\end{abstract}

Keywords: umbilical cord; sex differences; fetal programming; preclinical research

\section{Introduction}

Several diseases (cardiovascular, inflammatory and autoimmune diseases, diabetes mellitus, cancer, depression and brain disorders, and infections) are affected by sex differences in their diffusion, progression, and treatment [1-3]. Therefore, biological differences between sexes should be taken into account in all stages of research, from the pre-analytic conditions to genetics, epigenetics [4,5], developmental biology, biochemistry, physiology, pharmacology, toxicology, and epidemiology as well as social sciences, using all new technologies including omics [4].

Sexual dimorphism starts in utero and seems to occur at a pre-gonadal stage [6-8]. Moreover, fetal programming, which predispose developing organism to increased risk for future diseases appears to be strongly influenced by the fetus sex $[9,10]$.

Although sex-specific differences depend on animal species and strains, in most biomedical research, almost all cellular studies [11] do not differentiate between genetic male or female cells, and a high proportion of preclinical studies (68-76\%) use only males or do not report the sex of the animals [12,13]. Sex, in fact, should be considered in all cell studies, as it is now evident that different primary cells from males and females behave differently [14-22]. The stratification of cells according to the sex of donors become fundamental, because organelles and cells have memory of their sex $[15-19,23]$ and differences encountered in cellular compartments can be used as end points, biomarkers and/or targets of pharmacological studies [2].

The human umbilical cord has no particular ethical impediments, is non-tumorigenic, and less immunogenic, representing an advantageous experimental source over other 
cell sources $[24,25]$. Moreover, it seems a good experimental model for studying and understanding sex differences that characterize the cardiovascular system [1]. This selective review focuses on the current findings regarding sex differences observed in the umbilical cord, both in the blood and in the circulating cells, as well as in the different cellular models obtainable from it (Figure 1).

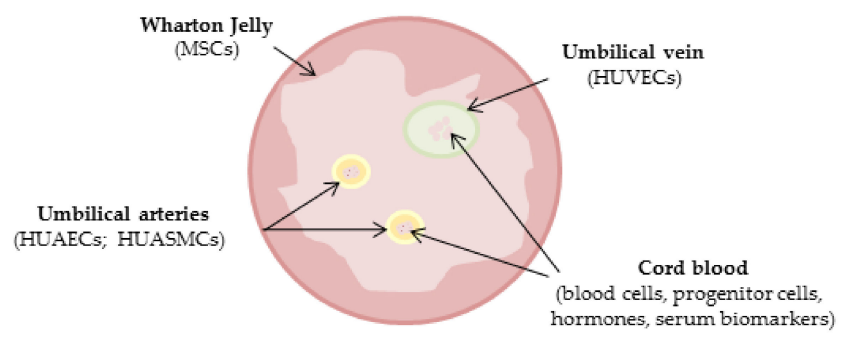

Figure 1. Schematic representation of human cord compartments.

\section{Strategy Search}

Literature analysis was performed using PubMed and Google as research tools using the following key-words and their combination: gender differences, sex differences, males, females, biomarkers, umbilical cord, cord blood, placenta, serum, plasma, progenitor cells, mononuclear cells, human umbilical vein endothelial cells (HUVECs), human umbilical artery endothelial cells (HUAECs), human umbilical artery smooth muscle cells (HUASMCs), Wharton Jelly (WJ), mesenchymal stem cells (MSCs), and fetal programming.

\section{Sex Differences in Fetal Growth and Placenta}

Sex determination occurs in two stages: in the first, sex chromosomes guide the differentiation of bipotential gonadal crests in the testis or ovary [26]. In the second stage, gonadal sex hormones drive the creation of a number of anatomical and physiological features known as phenotypic sex [27]. The inactivation of the $X$ chromosome is an important epigenetic process that occurs in mammalian females to correct the imbalance of the $\mathrm{X}$ chromosome genes between the sexes, a phenomenon that determines a transcriptional silencing aimed at obtaining an equal gene dosage; however, the silencing is often not complete $[28,29]$. In fact, $15-30 \%$ of human X-linked genes may escape this process, creating protein level differences between male and female individuals and making females more susceptible to certain diseases than males (such as autoimmune diseases), or protect them from other conditions such as cancer [29-32].

The upregulation/downregulation of transcription factors should initiate the differences in development, and the observation that sex-determining region Y (SRY) factor induces cell proliferation in the fetal mouse gonads [33] further emphasizes the importance of differential growth in sex determination and differentiation. SRY factor is an additional growth promoter gene that allows the $\mathrm{XY}$ embryo to differentiate into the female hormonal environment of the uterus. It is noteworthy that $\mathrm{XX}$ mice carrying a SRY-box transcription factor 9 (SOX9) transgene were found to develop as males [34], and that the importance of transcription factors is also reported by Colvin et al. [35] which showed that most XY mice lacking fibroblast growth factor 9 (FGF9) developed as females.

Female fetuses had smaller cord areas and less WJ than male fetuses, and male and female fetuses develop their length of the cord and relative placental weight differently from each other under the influence of umbilical ring constriction. Sex-specific differences in fetus growth appear early in the pregnancy and have long been recognized [36]. Cell division is more rapid in male embryos than in female ones [37], and male fetuses growth seems to be greater than the female ones. Crown-rump length and biparietal diameter (BPD) in human male fetuses are, on average, larger than in females from the first trimester until 15th week of gestation [38-40]. Moore described significant differences in head growth trajectories between male and female fetuses, showing that the head and abdominal circumferences were higher in male fetuses starting in the second trimester [41]. Moreover, 
Galjaard and colleagues observed that BPD and head circumference were significantly larger in males than in females from 20 weeks of gestation onwards [42]. These observations suggest that males may be both more responsive to growth promoting influences, and more susceptible to supply disturbances. Moreover, male fetuses are more active than female fetuses [43-45].

Anti-Müllerian hormone (AMH), a member of the transforming growth factor- $\beta$ (TGF$\beta$ ) super-family, is produced by Sertoli cells from the onset of testicular differentiation and by granulosa cells after birth in mammals [46], which play a role in sexual differentiation and recruitment. It binds to a serine-threonine kinase receptor complex consisting of ligandspecific type II receptors (AMHRII), recruiting and phosphorylating more general type I receptors also known as activin receptor-like protein kinases (ALKs). It plays key roles in the regression of the Müllerian duct in the male embryo. Indeed, gonadal sex steroids are necessary for the sexual differentiation of the fetus and for sexual maturation during prepubertal to pubertal age. In the stages of sexual maturation Sertoli and granulosa cells develop from a common precursor: the somatic cells expressing SRY differentiate into Sertoli cells and Leyding cells (testis), while somatic cells in which SRY is not expressed differentiate into granulosa cells and theca cells (ovary). The two groups of somatic cells subsequently acquire sex-specific functions, including the synthesis of sex steroids. AMH is at the crossroads of sexual determination and differentiation, and, after SRY and SOX9, it is the first product identified that characterizes Sertoli cells in mammals [46]. Human placenta and fetal membranes also express and co-localize AMH and AMHRII. Although no sex-related difference was found in their gene expression in both placenta and fetal membranes, intense staining for AMH in male fetal membranes supports $\mathrm{AMH}$ as a sex-specific hormone [47].

Sex differences in the placenta are also described: globally males have larger and heavier placenta, and birth weight/placental weight ratio than females [48-50]. The exact mechanism for these differences is unknown: some authors attribute it to sex differences in proliferation and metabolism at the earliest stages of blastocyst development [51-53], other reported males prioritize body growth, thus making them more vulnerable to sudden changes in fetal nutrition supply if they occur [48].

Moreover, placenta-associated pathologies are sexually divergent: chronic villitis and fetal thrombosis are more frequent in male placentas [54,55], while villous infarction is more common in females [54]. In addition, several sex differences are described in placenta gene expression, in hormonal asset, in immune response and hemodynamics [56-62], but this goes beyond the aims of this work and, therefore, will not be described in detail. As general examples, female placentas display higher expression of immune regulation genes, endocrine functions and placental growth [63,64], while male ones have more inflammatory profiles [65].

\section{Fetal Programming and Sex}

Fetal programming is the result of epigenetic changes that occurs in response to various stimuli that come from the environment that can affect the life and health of the baby even in adulthood [66]. According to Barker's hypothesis (thrifty phenotype hypothesis) intrauterine growth retardation, low birth weight, premature birth and a low availability of nutrients during the prenatal stage may increase the risk of metabolic disorders, including Type II diabetes, hypertension, and coronary heart disease in middle age [66]. There are several factors involved in fetal programming: maternal smoking, malnutrition, stress, hormones, physical and psychological violence suffered by the mother and the fetus sex $[9,10]$.

Fetal sex may affect the outcome of pregnancies: male sex is a risk factor for adverse pregnancy outcome, including preterm birth, premature rupture of membranes, gestational diabetes and macrosomia, motor and cognitive outcomes, and a lower likelihood of survival in intensive care $[48,67,68]$.

Many mechanisms, processes, and systems that are activated during fetal developmental programming, such as gene expression, DNA methylation, telomere and mitochondrial 
biology, the sympathetic nervous system, the renin angiotensin system, oxidative stress, and inflammation, act in a sex-specific way [69-72].

Moreover, male fetuses are heavier than female ones at birth, and therefore they invest more energy in growth, adapting less to maternal conditions, while the female fetus conserves more energy during growth and this allows it to adapt better to maternal conditions in multiple ways [73]. The male fetus of mothers with severe asthma, for example, shows signs of impairment including intrauterine growth restriction (IUGR), preterm labor and stillbirth [74,75]. Females, on the other hand, adapt to the maternal condition of chronic asthma by reducing their growth, resulting in smaller but not nonIUGR. It has also been reported that the presence of a male fetus is associated with a maternal microvascular constriction in pre-eclamptic women. In pregnant women of a female fetus, maternal microvascular function was not significantly different between normotensive and hypertensive women [76,77].

Consequently, for example, male fetuses have less probability of survival than females when faced with adversity, as females react to adversities with a variety of strategies, avoiding the risk of early mortality or morbidity but paying the price of increased vulnerability expressed later in the development and during the lifetime [78]. Male fetuses in fact, invest resources in growth, and this strategy can contribute to their greater size at birth, but also to a relative poverty of resources to respond to subsequent exposure to stress and adversity. Because the male fetus has not conserved its resources, it has a limited ability to adapt to adversity and a greater risk of morbidity and mortality. By contrast, the female fetus does not invest so much in growth but conserves resources and adapts to maternal conditions in different ways $[73,79,80]$.

\section{Umbilical Cord}

The umbilical cord contains two arteries that carry deoxygenated, nutrient-depleted blood away, and a vein, which carries oxygenated, nutrient-rich blood to the fetus [81,82].

The umbilical artery is made up of two main layers: an outer layer of muscle cells is found in a circular fashion and an inner layer with more irregularly available cells. The smooth muscle cells of the layer are poorly differentiated, containing only myofilaments [82].

Moreover, the umbilical cord contains WJ, a gelatinous substance made largely from mucopolysaccharides, which protects the blood vessels inside. WJ is enveloped in amniotic epithelium or, at the fetal end, a Malpighian keratinized epithelium, and it is a tissue that is active metabolically, involved in fluid exchange between umbilical vessels and amniotic fluid [83]. WJ is the primitive connective tissue of the human umbilical cord, described for the first time by Thomas Wharton in 1656 [84]. Subsequently, research efforts have attempted to optimize the isolation and differentiation of these cells from WJ $[85,86]$.

An umbilical abnormality is represented by the presence of a single umbilical artery (SUA), a malformation that occurs when only one artery instead of two is present. In most cases, the baby is completely normal and healthy, but in a small percentage of babies the presence of a 2-vessel cord could indicate the presence of other abnormalities, sometimes life-threatening [87]. In fact, this condition may be associated with fetal growth restriction and increased perinatal mortality [87-89] and other birth defects, such as spina bifida associated with hydrocephalus [90]. Several studies reported that SUA is more common in female than male babies and is associated with multiparity and advanced maternal age $[88,91-93]$. Only one study describes a greater frequency of SUA in male than in female babies with an association with multiparity and advanced maternal age [90].

Moreover, the umbilical coiling index (number of 360-degree spiral course of umbilical vessels, and predictor of pregnancy outcome and risk of low birth weight [94]) is reported to be significantly higher in female than in male newborns, due to higher number of cord coils, without any difference in cord length [95].

Morphology of the umbilical cord may be dependent on the mother's condition during pregnancy. It has been reported that in pre-eclamptic women there was an increase in the total area of the vessel, the total area of the vein, the total luminal area of the vein 
and the thickness of the wall of the arteries; the jelly area and the thickness of the vein wall decreased compared to the disease-free group [96]. In smoking pregnant women, umbilical arteries shows a thicker endothelial tissue with a different cell displacement [97]. Moreover, umbilical cord from smokers suffering of IUGR display a higher content of WJ and a decreased area of the umbilical vessels in comparison with healthy samples [98]. In addition, A recent systematic review and meta-analysis aimed to assess the association of fetal sex with multiple maternal complications; on 74 studies selected, the occurrence of pregnancy complications differed according to fetal sex with a higher cardiovascular and metabolic load for the mother in the presence of a male fetus. All pregnancy complications (i.e., gestational hypertension, total pre-eclampsia, eclampsia, placental abruption, and post-partum hemorrhage) tended to be associated with male fetal sex, except for preterm pre-eclampsia, which was more associated with female fetal sex [99].

\section{Sex Differences in Cord Blood Cells, Plasma and Serum}

Numerous biomarkers are influenced by sex [2,100-105], and this is true also for cord blood, plasma and serum biomarkers (Table 1).

It has been reported that in serum from vein of male umbilical cord the concentration of total testosterone, free testosterone, and estradiol, and inhibin (an inhibitor of FSH) are higher than in females [106]. Moreover, the authors reported that dehydroepiandrosterone sulfate from arterial serum was higher than that from veins only in female samples [106], confirming that biochemical parameters may also depend on the site of blood sampling in a sex-specific way [5].

Umbilical cord concentrations of cortisol and corticosterone are higher in the female fetus $[107,108]$, while growth hormone (GH) is higher in male cords [109].

Some authors observed that cord plasma insulin and C-peptide concentrations were higher in female fetuses than in male ones, assuming a possible insulin resistance in females $[110,111]$. Moreover, umbilical cord concentrations of leptin are significantly increased in female fetuses, and it is associated with a higher placental weight only in females [112].

Some inflammatory and oxidative stress markers display a sexual dimorphism. For example, in plasma collected from premature twins the levels of 15-F(2t)-isoprostane (prostaglandin-like compounds formed in vivo from the free radical-catalyzed peroxidation of essential fatty acids) was higher in premature males than in premature females, and this sex differences in vulnerability to lipid oxidants that occurs early in life could represent a biological mechanism contributing to sex disparity later in life [113]. Moreover, glutathione levels are higher in segments of male umbilical cord vein perfused with tertbutylhydroperoxide, an inducer of oxidative stress [114]. It has been reported also that high prenatal exposure to carbon monoxide as air pollutant is associated with a significant reduction in cord blood mononuclear cell mitochondrial DNA copies, an oxidative stress biomarker, only in males [115].

Differences in DNA methylation are reported: cord blood from females have twice the number of methylated CpGs sites than males, which are associated with gene expression differences in many tissues such as brain, musculoskeletal, endocrinological and genitourinary [116].

Sex significantly affects cord blood complete blood count: male neonates have higher red blood cells, hemoglobin, hematocrit, and mean corpuscular hemoglobin concentration, and lower mean corpuscular volume, platelet and white blood cells counts than female neonates $[117,118]$. They also have higher lymphocyte, monocyte, eosinophil, basophil and lower neutrophil, metamyelocyte, myelocyte, and promyelocyte ratios than females [118]. Cord blood mononuclear cells are reported to be lower in males than in females. Moreover, CD34+ progenitor cells from male cord blood are significantly higher than those of female ones, and have higher capacity to produce colonies $[119,120]$. Moreover, a lower proportion of ILC2s (a type of innate lymphoid cell) are present in cord blood of human female neonates compared to males [121]. 
Fadini and colleagues reported that female newborns had a higher number of CD34+KDR+ endothelial progenitor cells than males [122]. Interestingly, progenitor cells from male and female cord blood display different gene expression: 1205 genes are upregulated in males and are related with sister chromatid segregation, chromosome segregation, neural precursor cell proliferation, mitotic sister chromatid segregation and positive regulation of cell proliferation. By contrast, 1313 genes related to platelet activation, response to wounding, wound healing, cell activation and blood coagulation are upregulated in females [119]. These differences are also associated with sexually different signaling pathway: males have high expression of CD5, CD8B, CD20, CD21, CD24, CD126, CD127 and interleukin-7, mainly associated with lymphocyte function, while high expression of CD41, CD42, CD61 and thrombopoietin, associated with platelet function characterized females [119].

Table 1. Sex differences in cord blood, plasma and serum.

\begin{tabular}{|c|c|c|c|c|}
\hline Parameters & Source & M vs. F & Comments & Reference \\
\hline Total and free testosterone & serum (venous) & $\mathrm{M}>\mathrm{F}$ & $\begin{array}{l}\text { Dehydroepiandrosterone sulfate from arterial } \\
\text { serum }>\text { than that from vein only in } \mathrm{F}\end{array}$ & [86] \\
\hline Estradiol & serum (venous) & $\mathrm{M}>\mathrm{F}$ & & [86] \\
\hline Inhibin & serum (venous) & $\mathrm{M}>\mathrm{F}$ & & [86] \\
\hline Cortisol and corticosterone & serum (arterial and venous) & $\mathrm{M}<\mathrm{F}$ & & {$[107,108]$} \\
\hline Growth hormone & serum (venous) & $\mathrm{M}>\mathrm{F}$ & & [109] \\
\hline Leptin & serum (arterial and venous) & $\mathrm{M}<\mathrm{F}$ & & [92] \\
\hline Insulin and C-peptide & plasma & $\mathrm{M}<\mathrm{F}$ & & {$[110,111]$} \\
\hline 15-F(2t)-isoprostane & plasma & $\mathrm{M}>\mathrm{F}$ & Premature twins & [93] \\
\hline Gluthatione & umbilical cord vein & $\mathrm{M}>\mathrm{F}$ & $\begin{array}{l}\text { Segments of umbilical cord vein perfused } \\
\text { with tert-butylhydroperoxide }\end{array}$ & [94] \\
\hline $\begin{array}{l}\text { Mononuclear cell mitochondrial } \\
\text { DNA copies }\end{array}$ & cord blood & $\mathrm{M}<\mathrm{F}$ & $\begin{array}{l}\text { After prenatal exposure to carbon monoxide } \\
\text { as air pollutant }\end{array}$ & [95] \\
\hline DNA methylation & cord blood & $\mathrm{M}<\mathrm{F}$ & Number of methylated CpGs sites & [116] \\
\hline Red blood cells & cord blood & $\mathrm{M}>\mathrm{F}$ & & {$[117,118]$} \\
\hline Hematocrit & cord blood & $\mathrm{M}>\mathrm{F}$ & & {$[117,118]$} \\
\hline Hemoglobin & cord blood & $\mathrm{M}>\mathrm{F}$ & & {$[117,118]$} \\
\hline $\begin{array}{l}\text { Mean corpuscular hemoglobin } \\
\text { concentration }\end{array}$ & cord blood & $\mathrm{M}>\mathrm{F}$ & & {$[117,118]$} \\
\hline Mean corpuscular volume & cord blood & $\mathrm{M}<\mathrm{F}$ & & {$[117,118]$} \\
\hline Platelets & cord blood & $\mathrm{M}<\mathrm{F}$ & & {$[117,118]$} \\
\hline White blood cells & cord blood & $\mathrm{M}<\mathrm{F}$ & $\begin{array}{l}\text { Lymphocyte, monocyte, eosinophil, } \\
\text { basophil }>\text { M, neutrophil, metamyelocyte, } \\
\text { myelocyte, and promyelocyte ratios }>\text { F }\end{array}$ & [118] \\
\hline CD34+ progenitor cells & cord blood & $\mathrm{M}>\mathrm{F}$ & M have higher capacity to produce colonies & {$[119,120]$} \\
\hline ILC2s & cord blood & $\mathrm{M}>\mathrm{F}$ & & [121] \\
\hline CD34 + KDR + progenitor cells & cord blood & $\mathrm{M}<\mathrm{F}$ & & [122] \\
\hline
\end{tabular}

$\mathrm{M}=$ males; $\mathrm{F}=$ females.

\section{Sex Differences in -HUVECs and HUAECs}

HUVECs are a widely used in vitro model for the study of endothelium physiology and pathology $[123,124]$. Endothelial function and dysfunction display sex differences [125-127], but, although this aspect is clear, many authors still use HUVECs without reporting the donor sex. However, when male and female HUVECs were separately studied many differences emerged. Firstly, it is possible to observe male and female phenotypes: a higher rate of proliferation and migration, and higher levels of both the gene and protein for nitric oxide synthase 3 are observed in female cells than in male ones [15,128]. By contrast male HUVECs seems to have a higher degree of constitutive autophagy (an homeostatic 
mechanism, which maintain also normal cardiovascular function and morphology, through the lysosomal apparatus [129,130]): beclin-1 and the ratio LC3-II/LC3-I (the hallmark of the degree of autophagy activation), molecules involved in the different stages of autophagy, are significantly higher in male HUVECs, while some autophagy regulators, such as the mammalian target of rapamycin (mTOR) and the protein kinase B (AKT) are similar [15].

Moreover, HUVECs from males resulted in being more apoptotic than female ones after serum starvation, while no significant sex differences were observed in the percentage of necrotic cells [131].

The gene and protein expression of estrogen receptors (ER $\alpha, E R \beta$ and GPER) and androgen receptor (AR) are not different between sexes [15], but no consensus exist on this aspect: some authors report that male and female HUVECs do not express ER $\alpha$, while ER $\beta$ and AR expression is similar [132], while others show that HUVECs of unknown sex lack $\mathrm{ER} \alpha$ and progesterone receptor (PR) type B (PRB) but express ER $\beta$ and PRA [133].

The vasoconstrictor thrombin is more efficient in female HUVECs than in male ones, in stimulating prostacyclin and prostaglandin E2 synthesis [134], and RLIP76, a Ral effector GTPase-activating protein, significantly altered the percentage of apoptosis only in female cells [135].

Many sex differences are reported with respect to tolerance to hypoxia, mRNA expression, and responses to shear stress $[132,136,137]$. Lorenz et al. demonstrate that 70 genes are differentially expressed between the sexes: female HUVECs have a larger levels of genes related to the immune response and some genes involved in metabolism (for example, leptin, insulin receptors and some apolipoproteins), and that they also have a greater capacity to form tubes and tolerate the stress of serum deprivation better than their male counterparts [136]. These results indicate that there are some sex differences in autosomal genes, common to both sexes, rather than through expression of sex chromosome genes or sex hormones [138], and these sex-associated differences in gene expression may strongly affect the risk, incidence, prevalence, severity and age-of-onset of many diseases $[139,140]$.

Moreover, a higher number of genes are up- or down-regulated in female HUVECs than in male ones, after shear stress induction: vascular cell adhesion protein 1 expression is down-regulated almost 22 times in female HUVECs and only 3.5 times in male HUVECs [136]. Finally, unstimulated male HUVECs release more monocyte chemoattractant protein 1 (MCP1) and interleukin 8 than female HUVECs [141]. A brief exposure to tert-butylhydroperoxide induces a higher mortality in male HUVECs than in female ones [142]. More recently it has been reported that male and female HUVECs diverged in their secretome: 20 proteins (mostly related to responses to stress, cytokine stimulus, and apoptosis) are more abundant in male cells, while only 3 proteins are more present in the female secretome (retinal dehydrogenase 1, 6-phosphogluconate dehydrogenase decarboxylating, and transitional endoplasmic reticulum ATPase) [131].

Using twin pairs to study sex differences in transcriptome, Hartaman and colleagues observed that HUVECs from twins of different sexes (male/female) had greater differences in their transcriptome (2528 differentially expressed gene versus 79 in the comparison boyboy versus girl-girl twins) than HUVECs from twins of the same sex (both male/male and female/female pairs). Females in boy/girl twins showed higher activation of endothelial pathways (endothelial to mesenchymal transition, hypoxia and nuclear factor-kappa B signaling), while males had significantly higher expression of Myc targets, oxidative phosphorylation and mTOR signaling [143]. Interestingly, some of the detected sex differences were maintained throughout life, confirming that sexual dimorphism starts in utero [143].

As regards HUAECs, no sex-related differences have been reported at present and to our knowledge, probably because they are a less used source of endothelial cells.

\section{Sex Differences in HUASMCs}

Few results are available about the influence of sex on HUASMCs. Cells from male and female neonates display sexual dimorphism in ER $\beta$ expression, with ER $\beta$ being more highly expressed in male-derived cells, while ER $\alpha$ is similarly expressed in both sexes [23]. 
$E R \alpha$ is also localized in HUASMCs starved for 5 days to allow for ER $\alpha$ up-regulation, and $E R \alpha$ is more highly expressed on average in HUASMCs from female donors than in HUASMCs from male donors [144].

Constitutive autophagy is similar between male and female HUASMCs, but they respond differently to pharmacological stimulations: serum starvation and rapamycin treatment (immunosuppressant and anticancer agent acting as a selective inhibitor of mTOR protein kinase, a pleiotropic agent in nutrient detection and signaling) [145] promote authophagy in both sexes, but especially in female cells increasing the LC3II/I ratio and decreasing the phosphorylation of the autophagic regulator mTOR. In addition, verapamil is able to increase LC3II/I ratio similarly in male and female HUASMCs, but it has a sex-specific effect in beclin-1 expression, indicating that treatments may activate sexually different signaling pathways in male and female HUASMCs autophagic process [23].

To the best of our knowledge, no further data on sex differences are available for a HUASMCs model.

However, it has been reported that proliferation of HUASMCs is inhibited by estrogen or progesterone at physiological concentrations, and this correlates to the inhibition of MAPK and MEK activities, while testosterone has no effect; unfortunately no indication of the infant's sex is provided [146].

\section{Sex Differences in WJ Cells}

The WJ cell population expresses the characteristic phenotype of MSCs, exhibiting plastic adhesion and the expression of CD90, CD73 and CD105 [147]. Moreover, there are no safe data on the expression of estrogen and androgen receptors but only some reports regarding the effect of estradiol or testosterone on these cells [148-150].

Amniotic fluid-derived MSCs and WJ-MSCs, among the various tissues sources of stem cells, represent a promising cell population due to their high pluripotency, and WJMSCs have also attracted interest for their banking and transplantation capacities [151,152].

Balzano et al. [153], recently, disclosed novel biomedical implications in WJ-MSCs related to the sex of the donor, thus providing additional cues to exploit their regenerative potential in allogenic transplantation. They reported significantly higher gene expression of octamer-binding transcription factor 4 (OCT4), pluripotency gene, and the DNA-methyltransferase epigenetic modulator gene (DNMT1) in males than in females, while no sex differences have been detected in the expression levels of other stemnessregulating genes such as SOX2, NANOG, and C-MYC [153]. In a later study, the authors suggest that sex may affect the potential and efficiency of WJ-MSCs differentiation and autophagy: no significant differences between males and females were observed for miR145-5p (target: OCT4 gene), and miR-185-3p (target: DNMT1 gene), while miR-148a-3p (target: OCT4 gene) was significantly lower in males. In addition, the autophagic marker LC3II/I ratio was higher in female cells than in male ones, indicating a higher constitutive autophagy in female cells [154].

Another study showed that baculoviral IAP repeat-containing protein 2 (BIRC2) and BIRC3 genes, which inhibit apoptosis by interfering with the activation of caspases, are higher, although not significantly, in WJ stem cells from male newborns, indicating, perhaps a sex difference in the sensitivity to apoptosis [155].

\section{Conclusions}

Understanding the sex-specific mechanisms underlying susceptibility to future diseases could lead to sex-specific preventive interventions during early childhood. From this overview of the available literature, it emerges that the sex variable is still often forgotten in experimental models. In fact, for some cell types, which may be important for understanding sex differences in the pathophysiology of the cardiovascular system, such as the one we have analyzed, there are no data. The knowledge of sex differences is fundamental to the improvement of therapeutic response, at least for cardiovascular diseases in both men and women, as they are the main cause of mortality and morbidity for both sexes. In 
the era of personalized medicine, it is clear that animals, organs, cells and organelles of male and female origin should be used for drug screening and in diagnostic procedures in order to provide sex-based medicine that could lead to new therapy approaches and strategies, increasing the adequacy and safety of therapy. The inclusion of XX cells and female animals in experiments and the analysis of data by sex can contribute to solving, at least in part, the problem of irreproducibility observed in preclinical biomedical research, paying particular attention to methodological problems [3]. Therefore, our key message is that it is no longer reasonable to ignore methodological issues in sex-specific research, because only awareness of these issues can lead to innovations. It is no longer sufficient to simply compare males and females on a range of health indicators, but there is a pressing need to use more sophisticated experimental designs, redefine old methods and develop new ones to produce new measures to study the influence of sex on health. A multilevel approach including molecular and cellular studies, the use of appropriate animal models, and well-designed human studies is required. In human research, experimental manipulation of prenatal stress and the intrauterine environment and access to many of the target tissues of interest, particularly in fetal life, are difficult to achieve. Therefore, for future research purposes, having simple experimental models available becomes primary for the comprehension of mechanisms of fetal programming.

Funding: This research received no external funding.

Institutional Review Board Statement: Not applicable.

Informed Consent Statement: Not applicable.

Data Availability Statement: Data sharing not applicable.

Acknowledgments: Ph. Doctor School in Biomedical Sciences, Address in Gender Medicine, Men, Woman and Child, Sassari University supported the study.

Conflicts of Interest: The authors declare no conflict of interest.

\begin{tabular}{ll} 
Abbreviations \\
AMH & $\begin{array}{l}\text { Anti-Müllerian hormone } \\
\text { protein kinase B }\end{array}$ \\
AKT & $\begin{array}{l}\text { baculoviral IAP repeat-containing protein } \\
\text { BIRC }\end{array}$ \\
BPD & biparietal diameter \\
DNMT1 & DNA-methyltransferase \\
ER $\alpha$ & estrogen receptor alpha \\
ER $\beta$ & estrogen receptor beta \\
FGF9 & fibroblast growth factor 9 \\
GH & growth hormone \\
GPER & G protein-coupled estrogen receptor \\
HUAEC & human umbilical artery endothelial cells \\
HUASMC & human umbilical artery smooth muscle cells \\
HUVECs & human umbilical vein endothelial cells \\
IUGR & intrauterine growth restriction \\
LC3 & microtubule-associated protein 1A/1B-light chain 3 \\
MCP1 & monocyte chemoattractant protein 1 \\
MSCs & mesenchymal stem cells \\
mTOR & mammalian target of rapamycin \\
OCT4 & octamer-binding transcription factor 4 \\
PR & progesterone receptor \\
SOX & SRY-box transcription factor \\
SRY & sex-determining region Y \\
SUA & single umbilical artery \\
TGF- $\beta$ & transforming growth factor- $\beta$ \\
WJ & Wharton Jelly \\
\hline
\end{tabular}




\section{References}

1. Legato, M.J. Principles of Gender-Specific Medicine. Gender in the Genomic Era, 3rd ed.; Elsevier Academic Press: Cambridge, MA, USA, 2017; p. 792.

2. Franconi, F.; Campesi, I. Sex impact on biomarkers, pharmacokinetics and pharmacodynamics. Curr. Med. Chem. 2017, 24, 2561-2575. [CrossRef]

3. Franconi, F.; Campesi, I.; Colombo, D.; Antonini, P. Sex-gender variable: Methodological recommendations for increasing scientific value of clinical studies. Cells 2019, 8, 476. [CrossRef]

4. Vige, A.; Gallou-Kabani, C.; Junien, C. Sexual dimorphism in non-Mendelian inheritance. Pediatr. Res. 2008, 63, 340-347. [CrossRef]

5. Franconi, F.; Rosano, G.; Campesi, I. Need for gender-specific pre-analytical testing: The dark side of the moon in laboratory testing. Int. J. Cardiol. 2015, 179, 514-535. [CrossRef]

6. Tzschoppe, A.; Rauh, M.; Goecke, T.W.; Yazdi, B.; Hart, N.; Siemer, J.; Schild, R.L.; Dotsch, J. Sex-specific differences in the concentration of tubular parameters in the amniotic fluid of second trimester fetuses. Prenat. Diagn. 2012, 32, 476-479. [CrossRef] [PubMed]

7. Challis, J.; Newnham, J.; Petraglia, F.; Yeganegi, M.; Bocking, A. Fetal sex and preterm birth. Placenta 2013, 34, 95-99. [CrossRef] [PubMed]

8. Franconi, F.; Brunelleschi, S.; Steardo, L.; Cuomo, V. Gender differences in drug responses. Pharmacol. Res. 2007, 55, 81-95. [CrossRef] [PubMed]

9. Minucci, D. Lifelong gender health programming in fetal life. Ital. J. Gend. Specif. Med. 2018, 4, 91-100.

10. Glezerman, M. Intrauterine development of sex differences-fetal programming. In Principles of Gender-Specific Medicine. Gender in the Genomic Era; Legato, M.J., Ed.; Academic Press: Cambridge, MA, USA, 2017; pp. 237-249.

11. Shah, K.; McCormack, C.E.; Bradbury, N.A. Do you know the sex of your cells? Am. J. Physiol. Cell Physiol. 2013, 306, C3-C18. [CrossRef]

12. Taylor, K.E.; Vallejo-Giraldo, C.; Schaible, N.S.; Zakeri, R.; Miller, V.M. Reporting of sex as a variable in cardiovascular studies using cultured cells. Biol. Sex Differ. 2011, 2, 11. [CrossRef]

13. Beery, A.K.; Zucker, I. Sex bias in neuroscience and biomedical research. Neurosci. Biobehav. Rev. 2011, 35, 565-572. [CrossRef] [PubMed]

14. Maselli, A.; Matarrese, P.; Straface, E.; Canu, S.; Franconi, F.; Malorni, W. Cell sex: A new look at cell fate studies. FASEB J. 2009, 23, 978-984. [CrossRef] [PubMed]

15. Addis, R.; Campesi, I.; Fois, M.; Capobianco, G.; Dessole, S.; Fenu, G.; Montella, A.; Cattaneo, M.G.; Vicentini, L.M.; Franconi, F. Human umbilical endothelial cells (HUVECs) have a sex: Characterisation of the phenotype of male and female cells. Biol. Sex Differ. 2014, 5, 18. [CrossRef] [PubMed]

16. Campesi, I.; Capobianco, G.; Dessole, S.; Occhioni, S.; Montella, A.; Franconi, F. Estrogenic compounds have divergent effects on human endothelial progenitor cell migration according to sex of the donor. J. Vasc. Res. 2015, 52, 273-278. [CrossRef] [PubMed]

17. Campesi, I.; Marino, M.; Montella, A.; Pais, S.; Franconi, F. Sex differences in estrogen receptor alpha and beta levels and activation status in LPS-stimulated human macrophages. J. Cell Physiol. 2016, 232, 340-345. [CrossRef]

18. Campesi, I.; Sanna, M.; Zinellu, A.; Carru, C.; Rubattu, L.; Bulzomi, P.; Seghieri, G.; Tonolo, G.; Palermo, M.; Rosano, G.; et al. Oral contraceptives modify DNA methylation and monocyte-derived macrophage function. Biol. Sex Differ. 2012, 3, 4. [CrossRef]

19. Pellegrini, M.; Bulzomi, P.; Lecis, M.; Leone, S.; Campesi, I.; Franconi, F.; Marino, M. Endocrine disruptors differently influence estrogen receptor beta and androgen receptor in male and female rat VSMC. J. Cell Physiol. 2014, 229, 1061-1068. [CrossRef]

20. McCrohon, J.A.; Death, A.K.; Nakhla, S.; Jessup, W.; Handelsman, D.J.; Stanley, K.K.; Celermajer, D.S. Androgen receptor expression is greater in macrophages from male than from female donors. A sex difference with implications for atherogenesis. Circulation 2000, 101, 224-226. [CrossRef]

21. Lopez-Ruiz, A.; Sartori-Valinotti, J.; Yanes, L.L.; Iliescu, R.; Reckelhoff, J.F. Sex differences in control of blood pressure: Role of oxidative stress in hypertension in females. Am. J. Physiol. Heart Circ. Physiol. 2008, 295, H466-H474. [CrossRef]

22. Malorni, W.; Straface, E.; Matarrese, P.; Ascione, B.; Coinu, R.; Canu, S.; Galluzzo, P.; Marino, M.; Franconi, F. Redox state and gender differences in vascular smooth muscle cells. FEBS Lett. 2008, 582, 635-642. [CrossRef]

23. Campesi, I.; Occhioni, S.; Capobianco, G.; Fois, M.; Montella, A.; Dessole, S.; Franconi, F. Sex-specific pharmacological modulation of autophagic process in human umbilical artery smooth muscle cells. Pharmacol. Res. 2016, 113, 166-174. [CrossRef] [PubMed]

24. Ribeiro, A.; Laranjeira, P.; Mendes, S.; Velada, I.; Leite, C.; Andrade, P.; Santos, F.; Henriques, A.; Graos, M.; Cardoso, C.M.; et al. Mesenchymal stem cells from umbilical cord matrix, adipose tissue and bone marrow exhibit different capability to suppress peripheral blood B, natural killer and T cells. Stem. Cell Res. Ther. 2013, 4, 125. [CrossRef] [PubMed]

25. Saleh, R.; Reza, H.M. Short review on human umbilical cord lining epithelial cells and their potential clinical applications. Stem. Cell Res. Ther. 2017, 8, 222. [CrossRef]

26. Parma, P.; Radi, O. Molecular mechanisms of sexual development. Sex Dev. 2012, 6, 7-17. [CrossRef] [PubMed]

27. Camerino, G.; Parma, P.; Radi, O.; Valentini, S. Sex determination and sex reversal. Curr. Opin. Genet. Dev. 2006, 16, 289-292. [CrossRef]

28. Patel, S.; Bonora, G.; Sahakyan, A.; Kim, R.; Chronis, C.; Langerman, J.; Fitz-Gibbon, S.; Rubbi, L.; Skelton, R.J.P.; Ardehali, R.; et al. Human embryonic stem cells do not change their X inactivation status during differentiation. Cell Rep. 2017, 18, 54-67. [CrossRef] 
29. Patrat, C.; Ouimette, J.F.; Rougeulle, C. X chromosome inactivation in human development. Development 2020, 147. [CrossRef]

30. Posynick, B.J.; Brown, C.J. Escape from X-Chromosome inactivation: An evolutionary perspective. Front. Cell Dev. Biol. 2019, 7, 241. [CrossRef]

31. Berletch, J.B.; Yang, F.; Xu, J.; Carrel, L.; Disteche, C.M. Genes that escape from X inactivation. Hum. Genet. 2011, 130, 237-245. [CrossRef]

32. Gribnau, J.; Barakat, S.T. X-chromosome inactivation and its implications for human disease. bioRxiv 2017, 076950. [CrossRef]

33. Schmahl, J.; Eicher, E.M.; Washburn, L.L.; Capel, B. Sry induces cell proliferation in the mouse gonad. Development 2000, 127, 65-73. [PubMed]

34. Vidal, V.P.; Chaboissier, M.C.; de Rooij, D.G.; Schedl, A. Sox9 induces testis development in XX transgenic mice. Nat. Genet. 2001, 28, 216-217. [CrossRef] [PubMed]

35. Colvin, J.S.; Green, R.P.; Schmahl, J.; Capel, B.; Ornitz, D.M. Male-to-female sex reversal in mice lacking fibroblast growth factor 9. Cell 2001, 104, 875-889. [CrossRef]

36. Lubchenco, L.O.; Hansman, C.; Dressler, M.; Boyd, E. Intrauterine Growth as Estimated from Liveborn Birth-Weight Data at 24 to 42 Weeks of Gestation. Pediatrics 1963, 32, 793-800.

37. Mittwoch, U. Blastocysts prepare for the race to be male. Hum. Reprod. 1993, 8, 1550-1555. [CrossRef]

38. Pedersen, J.F.; Mantoni, M. Difference in fetal size in the first trimester. Br. Med. J. (Clin. Res. Ed.) 1985, 291, 1278. [CrossRef]

39. Schwarzler, P.; Bland, J.M.; Holden, D.; Campbell, S.; Ville, Y. Sex-specific antenatal reference growth charts for uncomplicated singleton pregnancies at 15-40 weeks of gestation. Ultrasound Obstet. Gynecol. 2004, 23, 23-29. [CrossRef]

40. Broere-Brown, Z.A.; Baan, E.; Schalekamp-Timmermans, S.; Verburg, B.O.; Jaddoe, V.W.; Steegers, E.A. Sex-specific differences in fetal and infant growth patterns: A prospective population-based cohort study. Biol. Sex Differ. 2016, 7, 65. [CrossRef]

41. Moore, W.M.; Ward, B.S.; Jones, V.P.; Bamford, F.N. Sex difference in fetal head growth. Br. J. Obstet. Gynaecol. 1988, 95, $238-242$. [CrossRef]

42. Galjaard, S.; Ameye, L.; Lees, C.C.; Pexsters, A.; Bourne, T.; Timmerman, D.; Devlieger, R. Sex differences in fetal growth and immediate birth outcomes in a low-risk Caucasian population. Biol. Sex Differ. 2019, 10, 48. [CrossRef]

43. Lee, E.; Ping, H. Sex differences in fetal activity and childhood hyperactivity. Res. J. Dev. Biol. 2014, 1, 1-5.

44. Almli, C.R.; Ball, R.H.; Wheeler, M.E. Human fetal and neonatal movement patterns: Gender differences and fetal-to-neonatal continuity. Dev. Psychobiol. 2001, 38, 252-273. [CrossRef] [PubMed]

45. DiPietro, J.A.; Hodgson, D.M.; Costigan, K.A.; Hilton, S.C.; Johnson, T.R. Fetal neurobehavioral development. Child. Dev. 1996, 67, 2553-2567. [CrossRef] [PubMed]

46. Oreal, E.; Mazaud, S.; Picard, J.Y.; Magre, S.; Carre-Eusebe, D. Different patterns of anti-Mullerian hormone expression, as related to DMRT1, SF-1, WT1, GATA-4, Wnt-4, and Lhx9 expression, in the chick differentiating gonads. Dev. Dyn. 2002, 225, $221-232$. [CrossRef]

47. Novembri, R.; Funghi, L.; Voltolini, C.; Belmonte, G.; Vannuccini, S.; Torricelli, M.; Petraglia, F. Placenta expresses anti-Mullerian hormone and its receptor: Sex-related difference in fetal membranes. Placenta 2015, 36, 731-737. [CrossRef]

48. Eriksson, J.G.; Kajantie, E.; Osmond, C.; Thornburg, K.; Barker, D.J. Boys live dangerously in the womb. Am. J. Hum. Biol. 2010, 22, 330-335. [CrossRef]

49. Wallace, J.M.; Bhattacharya, S.; Horgan, G.W. Gestational age, gender and parity specific centile charts for placental weight for singleton deliveries in Aberdeen, UK. Placenta 2013, 34, 269-274. [CrossRef]

50. Ogawa, M.; Matsuda, Y.; Nakai, A.; Hayashi, M.; Sato, S.; Matsubara, S. Standard curves of placental weight and fetal/placental weight ratio in Japanese population: Difference according to the delivery mode, fetal sex, or maternal parity. Eur. J. Obstet. Gynecol. Reprod. Biol. 2016, 206, 225-231. [CrossRef]

51. Bermejo-Alvarez, P.; Rizos, D.; Rath, D.; Lonergan, P.; Gutierrez-Adan, A. Epigenetic differences between male and female bovine blastocysts produced in vitro. Physiol. Genom. 2008, 32, 264-272. [CrossRef]

52. Valdivia, R.P.; Kunieda, T.; Azuma, S.; Toyoda, Y. PCR sexing and developmental rate differences in preimplantation mouse embryos fertilized and cultured in vitro. Mol. Reprod. Dev. 1993, 35, 121-126. [CrossRef]

53. Ray, P.F.; Conaghan, J.; Winston, R.M.; Handyside, A.H. Increased number of cells and metabolic activity in male human preimplantation embryos following in vitro fertilization. J. Reprod. Fertil. 1995, 104, 165-171. [CrossRef]

54. Leon-Garcia, S.M.; Roeder, H.A.; Nelson, K.K.; Liao, X.; Pizzo, D.P.; Laurent, L.C.; Parast, M.M.; LaCoursiere, D.Y. Maternal obesity and sex-specific differences in placental pathology. Placenta 2016, 38, 33-40. [CrossRef] [PubMed]

55. Sheiner, E.; Levy, A.; Katz, M.; Hershkovitz, R.; Leron, E.; Mazor, M. Gender does matter in perinatal medicine. Fetal Diagn. Ther. 2004, 19, 366-369. [CrossRef] [PubMed]

56. Steier, J.A.; Myking, O.L.; Bergsjo, P.B. Correlation between fetal sex and human chorionic gonadotropin in peripheral maternal blood and amniotic fluid in second and third trimester normal pregnancies. Acta Obstet. Gynecol. Scand. 1999, 78, 367-371. [PubMed]

57. Clifton, V.L.; Bisits, A.; Zarzycki, P.K. Characterization of human fetal cord blood steroid profiles in relation to fetal sex and mode of delivery using temperature-dependent inclusion chromatography and principal component analysis (PCA). J. Chromatogr. B Anal. Technol. Biomed. Life Sci. 2007, 855, 249-254. [CrossRef] 
58. Goldenberg, R.L.; Andrews, W.W.; Faye-Petersen, O.M.; Goepfert, A.R.; Cliver, S.P.; Hauth, J.C. The Alabama Preterm Birth Study: Intrauterine infection and placental histologic findings in preterm births of males and females less than 32 weeks. Am. J. Obstet. Gynecol. 2006, 195, 1533-1537. [CrossRef]

59. Scott, N.M.; Hodyl, N.A.; Murphy, V.E.; Osei-Kumah, A.; Wyper, H.; Hodgson, D.M.; Smith, R.; Clifton, V.L. Placental cytokine expression covaries with maternal asthma severity and fetal sex. J. Immunol. 2009, 182, 1411-1420. [CrossRef]

60. Widnes, C.; Flo, K.; Wilsgaard, T.; Kiserud, T.; Acharya, G. Sex differences in umbilical artery Doppler indices: A longitudinal study. Biol. Sex Differ. 2018, 9, 16. [CrossRef]

61. Dawes, N.W.; Dawes, G.S.; Moulden, M.; Redman, C.W. Fetal heart rate patterns in term labor vary with sex, gestational age, epidural analgesia, and fetal weight. Am. J. Obstet. Gynecol. 1999, 180, 181-187. [CrossRef]

62. Bale, T.L. The placenta and neurodevelopment: Sex differences in prenatal vulnerability. Dialogues Clin. Neurosci. 2016, 18, $459-464$.

63. Sood, R.; Zehnder, J.L.; Druzin, M.L.; Brown, P.O. Gene expression patterns in human placenta. Proc. Natl. Acad. Sci. USA 2006, 103, 5478-5483. [CrossRef] [PubMed]

64. Buckberry, S.; Bianco-Miotto, T.; Bent, S.J.; Dekker, G.A.; Roberts, C.T. Integrative transcriptome meta-analysis reveals widespread sex-biased gene expression at the human fetal-maternal interface. Mol. Hum. Reprod. 2014, 20, 810-819. [CrossRef] [PubMed]

65. Cvitic, S.; Longtine, M.S.; Hackl, H.; Wagner, K.; Nelson, M.D.; Desoye, G.; Hiden, U. The human placental sexome differs between trophoblast epithelium and villous vessel endothelium. PLoS ONE 2013, 8, e79233. [CrossRef] [PubMed]

66. Barker, D.J. Intrauterine programming of adult disease. Mol. Med. Today 1995, 1, 418-423. [CrossRef]

67. Di Renzo, G.C.; Rosati, A.; Sarti, R.D.; Cruciani, L.; Cutuli, A.M. Does fetal sex affect pregnancy outcome? Gend. Med. 2007, 4, 19-30. [CrossRef]

68. Verburg, P.E.; Tucker, G.; Scheil, W.; Erwich, J.J.; Dekker, G.A.; Roberts, C.T. Sexual Dimorphism in Adverse Pregnancy OutcomesA Retrospective Australian Population Study 1981-2011. PLoS ONE 2016, 11, e0158807. [CrossRef]

69. Martinez, D.; Pentinat, T.; Ribo, S.; Daviaud, C.; Bloks, V.W.; Cebria, J.; Villalmanzo, N.; Kalko, S.G.; Ramon-Krauel, M.; Diaz, R.; et al. In utero undernutrition in male mice programs liver lipid metabolism in the second-generation offspring involving altered Lxra DNA methylation. Cell Metab. 2014, 19, 941-951. [CrossRef]

70. Moritz, K.M.; Cuffe, J.S.; Wilson, L.B.; Dickinson, H.; Wlodek, M.E.; Simmons, D.G.; Denton, K.M. Review: Sex specific programming: A critical role for the renal renin-angiotensin system. Placenta 2010, 31, S40-S46. [CrossRef]

71. Grigore, D.; Ojeda, N.B.; Alexander, B.T. Sex differences in the fetal programming of hypertension. Gend. Med. 2008, 5 (Suppl. A), S121-S132. [CrossRef]

72. Dasinger, J.H.; Alexander, B.T. Gender differences in developmental programming of cardiovascular diseases. Clin. Sci. (Lond.) 2016, 130, 337-348. [CrossRef]

73. Clifton, V.L. Review: Sex and the human placenta: Mediating differential strategies of fetal growth and survival. Placenta 2010, 31, S33-S39. [CrossRef] [PubMed]

74. Murphy, V.E.; Gibson, P.; Talbot, P.I.; Clifton, V.L. Severe asthma exacerbations during pregnancy. Obstet. Gynecol. 2005, 106, 1046-1054. [CrossRef] [PubMed]

75. Clark, J.M.; Hulme, E.; Devendrakumar, V.; Turner, M.A.; Baker, P.N.; Sibley, C.P.; D'Souza, S.W. Effect of maternal asthma on birthweight and neonatal outcome in a British inner-city population. Paediatr. Perinat. Epidemiol. 2007, 21, 154-162. [CrossRef]

76. Stark, M.J.; Clifton, V.L.; Wright, I.M. Neonates born to mothers with preeclampsia exhibit sex-specific alterations in microvascular function. Pediatr. Res. 2009, 65, 292-295. [CrossRef] [PubMed]

77. Stark, M.J.; Dierkx, L.; Clifton, V.L.; Wright, I.M. Alterations in the maternal peripheral microvascular response in pregnancies complicated by preeclampsia and the impact of fetal sex. J. Soc. Gynecol. Investig. 2006, 13, 573-578. [CrossRef]

78. Sandman, C.A.; Glynn, L.M.; Davis, E.P. Is there a viability-vulnerability tradeoff? Sex differences in fetal programming. J. Psychosom. Res. 2013, 75, 327-335. [CrossRef]

79. Wells, J.C. Natural selection and sex differences in morbidity and mortality in early life. J. Theor. Biol. 2000, 202, 65-76. [CrossRef]

80. Cooperstock, M.; Campbell, J. Excess males in preterm birth: Interactions with gestational age, race, and multiple birth. Obstet. Gynecol. 1996, 88, 189-193. [CrossRef]

81. Spurway, J.; Logan, P.; Pak, S. The development, structure and blood flow within the umbilical cord with particular reference to the venous system. Australas. J. Ultrasound Med. 2012, 15, 97-102. [CrossRef]

82. Meyer, W.W.; Rumpelt, H.J.; Yao, A.C.; Lind, J. Structure and closure mechanism of the human umbilical artery. Eur. J. Pediatr. 1978, 128, 247-259. [CrossRef]

83. Tavares Fortuna, J.F.; Lourdes Pratas, M. Coarctation of the umbilical cord: A cause of intrauterine fetal death. Int. J. Gynaecol. Obstet. 1978, 15, 469-473. [CrossRef] [PubMed]

84. Wharton, T.W. Adenographia; Freer, S., Ed.; Oxford University Press: Oxford, UK, 1996; p. 243.

85. Takechi, K.; Kuwabara, Y.; Mizuno, M. Ultrastructural and immunohistochemical studies of Wharton's jelly umbilical cord cells. Placenta 1993, 14, 235-245. [CrossRef]

86. Kim, D.W.; Staples, M.; Shinozuka, K.; Pantcheva, P.; Kang, S.D.; Borlongan, C.V. Wharton's jelly-derived mesenchymal stem cells: Phenotypic characterization and optimizing their therapeutic potential for clinical applications. Int. J. Mol. Sci. 2013, 14, 11692-11712. [CrossRef] [PubMed] 
87. Geipel, A.; Germer, U.; Welp, T.; Schwinger, E.; Gembruch, U. Prenatal diagnosis of single umbilical artery: Determination of the absent side, associated anomalies, Doppler findings and perinatal outcome. Ultrasound Obstet. Gynecol. 2000, 15, $114-117$. [CrossRef] [PubMed]

88. Luo, X.; Zhai, S.; Shi, N.; Li, M.; Cui, S.; Xu, Y.; Ran, L.; Ren, L.; Hong, T.; Liu, R. The risk factors and neonatal outcomes of isolated single umbilical artery in singleton pregnancy: A meta-analysis. Sci. Rep. 2017, 7, 7396. [CrossRef] [PubMed]

89. Mu, S.C.; Lin, C.H.; Chen, Y.L.; Sung, T.C.; Bai, C.H.; Jow, G.M. The perinatal outcomes of asymptomatic isolated single umbilical artery in full-term neonates. Pediatr. Neonatol. 2008, 49, 230-233. [CrossRef]

90. Elghazaly, A.E.; Jameel, A. Morphological features of the umbilical cord vessels at the delivery, in sudanese neonates. Int. J. Anat. Res. 2020, 8, 7200-7206. [CrossRef]

91. Fujikura, T. Fused umbilical arteries near placental cord insertion. Am. J. Obstet. Gynecol. 2003, 188, 765-767. [CrossRef]

92. Heifetz, S.A. Single umbilical artery. A statistical analysis of 237 autopsy cases and review of the literature. Perspect. Pediatr. Pathol. 1984, 8, 345-378.

93. Lilja, M. Infants with single umbilical artery studied in a national registry. General epidemiological characteristics. Paediatr. Perinat. Epidemiol. 1991, 5, 27-36. [CrossRef]

94. Chitra, T.; Sushanth, Y.S.; Raghavan, S. Umbilical coiling index as a marker of perinatal outcome: An analytical study. Obstet. Gynecol. Int. 2012, 2012, 213689. [CrossRef] [PubMed]

95. Ochshorn, Y.; Ascher Landsberg, J.; Many, A.; Maslovitz, S.; Rimon, E.; Yogev, Y. Fetal gender and umbilical cord characteristics at birth. J. Matern. Fetal Neonatal Med. 2019, 1-4. [CrossRef]

96. Barnwal, M.; Rathi, S.; Chhabra, S.; Nanda, S. Histomorphometry of umbilical cord and its vessels in pre- eclampsia as compared to normal pregnancies. Nepal J. Obstet. Gynaecol. 2013, 7, 28-32. [CrossRef]

97. Rua Ede, A.; Porto, M.L.; Ramos, J.P.; Nogueira, B.V.; Meyrelles, S.S.; Vasquez, E.C.; Pereira, T.C. Effects of tobacco smoking during pregnancy on oxidative stress in the umbilical cord and mononuclear blood cells of neonates. J. Biomed. Sci. 2014, 21, 105. [PubMed]

98. Milnerowicz-Nabzdyk, E.; Zimmer, M.; Tlolka, J.; Michniewicz, J.; Pomorski, M.; Wiatrowski, A. Umbilical cord morphology in pregnancies complicated by IUGR in cases of tobacco smoking and pregnancy-induced hypertension. Neuro Endocrinol. Lett. 2010, 31, 842-847.

99. Broere-Brown, Z.A.; Adank, M.C.; Benschop, L.; Tielemans, M.; Muka, T.; Goncalves, R.; Bramer, W.M.; Schoufour, J.D.; Voortman, T.; Steegers, E.A.P.; et al. Fetal sex and maternal pregnancy outcomes: A systematic review and meta-analysis. Biol. Sex Differ. 2020, 11, 26. [CrossRef]

100. Mittelstrass, K.; Ried, J.S.; Yu, Z.; Krumsiek, J.; Gieger, C.; Prehn, C.; Roemisch-Margl, W.; Polonikov, A.; Peters, A.; Theis, F.J.; et al. Discovery of sexual dimorphisms in metabolic and genetic biomarkers. PLoS Genet. 2011, 7, e1002215. [CrossRef]

101. Caterino, M.; Ruoppolo, M.; Villani, G.R.D.; Marchese, E.; Costanzo, M.; Sotgiu, G.; Dore, S.; Franconi, F.; Campesi, I. Influence of sex on urinary organic acids: A cross-sectional study in children. Int. J. Mol. Sci. 2020, 21, 582. [CrossRef]

102. Ruoppolo, M.; Campesi, I.; Scolamiero, E.; Pecce, R.; Caterino, M.; Cherchi, S.; Mercuro, G.; Tonolo, G.; Franconi, F. Serum metabolomic profiles suggest influence of sex and oral contraceptive use. Am. J. Transl. Res. 2014, 6, 614-624.

103. Ruoppolo, M.; Scolamiero, E.; Caterino, M.; Mirisola, V.; Franconi, F.; Campesi, I. Female and male human babies have distinct blood metabolomic patterns. Mol. Biosyst. 2015, 11, 2483-2492. [CrossRef]

104. Ishikawa, M.; Maekawa, K.; Saito, K.; Senoo, Y.; Urata, M.; Murayama, M.; Tajima, Y.; Kumagai, Y.; Saito, Y. Plasma and serum lipidomics of healthy white adults shows characteristic profiles by subjects' gender and age. PLoS ONE 2014, 9, e91806. [CrossRef] [PubMed]

105. Reuter, S.E.; Evans, A.M.; Chace, D.H.; Fornasini, G. Determination of the reference range of endogenous plasma carnitines in healthy adults. Ann. Clin. Biochem. 2008, 45, 585-592. [CrossRef] [PubMed]

106. Simmons, D.; France, J.T.; Keelan, J.A.; Song, L.; Knox, B.S. Sex differences in umbilical cord serum levels of inhibin, testosterone, oestradiol, dehydroepiandrosterone sulphate, and sex hormone-binding globulin in human term neonates. Biol. Neonate 1994, 65, 287-294. [CrossRef] [PubMed]

107. Wynne-Edwards, K.E.; Lee, K.; Zhou, R.; Edwards, H.E. Sex differences in substrates and clearance products of cortisol and corticosterone synthesis in full-term human umbilical circulation without labor: Substrate depletion matches synthesis in males, but not females. Psychoneuroendocrinology 2019, 109, 104381. [CrossRef] [PubMed]

108. Giesbrecht, G.F.; Rash, J.A.; Edwards, H.E.; Wynne-Edwards, K.E. Full-term deliveries without antecedent labor reveal sex differences in umbilical cord glucocorticoid concentrations. Psychoneuroendocrinology 2016, 74, 121-125. [CrossRef]

109. Fukaya, T.; Furuhashi, N.; Kono, H.; Tachibana, Y.; Shinkawa, O.; Takahashi, T.; Suzuki, M. Secretion and Sex differences in cord serum growth hormone levels of the human fetus (author's transl). Nihon Sanka Fujinka Gakkai Zasshi 1982, 34, 491-496.

110. Kuchay, M.S.; Kudyar, R.P.; Gupta, A.; Pandita, K.K.; Ganie, M.A. Gender differences in insulin and C-peptide concentrations at birth using cord blood collection. Arch. Endocrinol. Metab. 2016, 60, 264-266. [CrossRef]

111. Shields, B.M.; Knight, B.; Hopper, H.; Hill, A.; Powell, R.J.; Hattersley, A.T.; Clark, P.M. Measurement of cord insulin and insulin-related peptides suggests that girls are more insulin resistant than boys at birth. Diabetes Care 2007, 30, 2661-2666. [CrossRef]

112. Tome, M.A.; Lage, M.; Camina, J.P.; Garcia-Mayor, R.V.; Dieguez, C.; Casanueva, F.F. Sex-based differences in serum leptin concentrations from umbilical cord blood at delivery. Eur. J. Endocrinol. 1997, 137, 655-658. [CrossRef] 
113. Minghetti, L.; Greco, A.; Zanardo, V.; Suppiej, A. Early-life sex-dependent vulnerability to oxidative stress: The natural twining model. J. Matern. Fetal Neonatal. Med. 2013, 26, 259-262. [CrossRef]

114. Lavoie, J.C.; Chessex, P. Gender-related response to a tert-butyl hydroperoxide-induced oxidation in human neonatal tissue. Free Radic. Biol. Med. 1994, 16, 307-313. [CrossRef]

115. Kaali, S.; Jack, D.; Delimini, R.; Hu, L.; Burkart, K.; Opoku-Mensah, J.; Quinn, A.; Ae-Ngibise, K.A.; Wylie, B.; Boamah-Kaali, E.A.; et al. Prenatal Household Air Pollution Alters Cord Blood Mononuclear Cell Mitochondrial DNA Copy Number: Sex-Specific Associations. Int. J. Environ. Res. Public Health 2019, 16, 26. [CrossRef]

116. Maschietto, M.; Bastos, L.C.; Tahira, A.C.; Bastos, E.P.; Euclydes, V.L.; Brentani, A.; Fink, G.; de Baumont, A.; Felipe-Silva, A.; Francisco, R.P.; et al. Sex differences in DNA methylation of the cord blood are related to sex-bias psychiatric diseases. Sci. Rep. 2017, 7, 44547. [CrossRef] [PubMed]

117. Glasser, L.; Sutton, N.; Schmeling, M.; Machan, J.T. A comprehensive study of umbilical cord blood cell developmental changes and reference ranges by gestation, gender and mode of delivery. J. Perinatol. 2015, 35, 469-475. [CrossRef] [PubMed]

118. Chang, Y.H.; Yang, S.H.; Wang, T.F.; Lin, T.Y.; Yang, K.L.; Chen, S.H. Complete blood count reference values of cord blood in Taiwan and the influence of gender and delivery route on them. Pediatr. Neonatol. 2011, 52, 155-160. [CrossRef] [PubMed]

119. Zhou, L.; Che, Z.; Zhang, X.; Zhou, P.; Li, X.; Xu, X.; Shi, Q.; Li, D.; Ju, X. Influence of neonatal gender on cord blood CD34(+) cell amplification and gene expression. Exp. Ther. Med. 2019, 18, 105-118. [CrossRef]

120. Aroviita, P.; Teramo, K.; Hiilesmaa, V.; Kekomaki, R. Cord blood hematopoietic progenitor cell concentration and infant sex. Transfusion 2005, 45, 613-621. [CrossRef]

121. Forsberg, A.; Bengtsson, M.; Eringfalt, A.; Ernerudh, J.; Mjosberg, J.; Jenmalm, M.C. GATA binding protein 3(+) group 2 innate lymphoid cells are present in cord blood and in higher proportions in male than in female neonates. J. Allergy Clin. Immunol. 2014, 134, 228-230. [CrossRef]

122. Fadini, G.P.; de Kreutzenberg, S.; Albiero, M.; Coracina, A.; Pagnin, E.; Baesso, I.; Cignarella, A.; Bolego, C.; Plebani, M.; Nardelli, G.B.; et al. Gender differences in endothelial progenitor cells and cardiovascular risk profile: The role of female estrogens. Arterioscler. Thromb. Vasc. Biol. 2008, 28, 997-1004. [CrossRef]

123. Onat, D.; Brillon, D.; Colombo, P.C.; Schmidt, A.M. Human vascular endothelial cells: A model system for studying vascular inflammation in diabetes and atherosclerosis. Curr. Diab. Rep. 2011, 11, 193-202. [CrossRef]

124. Cines, D.B.; Pollak, E.S.; Buck, C.A.; Loscalzo, J.; Zimmerman, G.A.; McEver, R.P.; Pober, J.S.; Wick, T.M.; Konkle, B.A.; Schwartz, B.S.; et al. Endothelial cells in physiology and in the pathophysiology of vascular disorders. Blood 1998, 91, 3527-3561. [PubMed]

125. Franconi, F.; Rosano, G.; Basili, S.; Montella, A.; Campesi, I. Human cells involved in atherosclerosis have a sex. Int. J. Cardiol. 2016, 228, 983-1001. [CrossRef] [PubMed]

126. Koller, A. Perspectives: Microvascular endothelial dysfunction and gender. Eur. Heart J. Suppl. 2014, 16, A16-A19. [CrossRef] [PubMed]

127. Cao, C.; Hu, J.; Dong, Y.; Zhan, R.; Li, P.; Su, H.; Peng, Q.; Wu, T.; Lei, L.; Huang, X.; et al. Gender differences in the risk factors for endothelial dysfunction in Chinese hypertensive patients: Homocysteine is an independent risk factor in females. PLoS ONE 2015, 10, e0118686. [CrossRef]

128. Cattaneo, M.G.; Vanetti, C.; Decimo, I.; Di Chio, M.; Martano, G.; Garrone, G.; Bifari, F.; Vicentini, L.M. Sex-specific eNOS activity and function in human endothelial cells. Sci. Rep. 2017, 7, 9612. [CrossRef]

129. Oczypok, E.A.; Oury, T.D.; Chu, C.T. It's a cell-eat-cell world: Autophagy and phagocytosis. Am. J. Pathol. 2013, 182, 612-622. [CrossRef]

130. De Meyer, G.R.; Martinet, W. Autophagy in the cardiovascular system. Biochim. Biophys. Acta 2009, 1793, 1485-1495. [CrossRef]

131. Cattaneo, M.G.; Banfi, C.; Brioschi, M.; Lattuada, D.; Vicentini, L.M. Sex-Dependent Differences in the Secretome of Human Endothelial Cells. Biol. Sex Differ. 2021, 12, 7. [CrossRef]

132. Annibalini, G.; Agostini, D.; Calcabrini, C.; Martinelli, C.; Colombo, E.; Guescini, M.; Tibollo, P.; Stocchi, V.; Sestili, P. Effects of sex hormones on inflammatory response in male and female vascular endothelial cells. J. Endocrinol. Investig. 2014, 37, 861-869. [CrossRef]

133. Toth, B.; Saadat, G.; Geller, A.; Scholz, C.; Schulze, S.; Friese, K.; Jeschke, U. Human umbilical vascular endothelial cells express estrogen receptor beta (ERbeta) and progesterone receptor A (PR-A), but not ERalpha and PR-B. Histochem. Cell Biol. 2008, 130, 399-405. [CrossRef]

134. Batres, R.O.; Dupont, J. Gender differences in prostacyclin and prostaglandin E2 synthesis by human endothelial cells. Prostaglandins Leukot. Med. 1986, 22, 159-171. [CrossRef]

135. Matarrese, P.; Colasanti, T.; Ascione, B.; Margutti, P.; Franconi, F.; Alessandri, C.; Conti, F.; Riccieri, V.; Rosano, G.; Ortona, E.; et al. Gender disparity in susceptibility to oxidative stress and apoptosis induced by autoantibodies specific to RLIP76 in vascular cells. Antioxid. Redox Signal. 2011, 15, 2825-2836. [CrossRef] [PubMed]

136. Lorenz, M.; Koschate, J.; Kaufmann, K.; Kreye, C.; Mertens, M.; Kuebler, W.M.; Baumann, G.; Gossing, G.; Marki, A.; Zakrzewicz, A.; et al. Does cellular sex matter? Dimorphic transcriptional differences between female and male endothelial cells. Atherosclerosis 2015, 240, 61-72. [CrossRef] [PubMed]

137. Zhang, Y.; Lingappan, K. Differential sex-specific effects of oxygen toxicity in human umbilical vein endothelial cells. Biochem. Biophys. Res. Commun. 2017, 486, 431-437. [CrossRef] 
138. Wijchers, P.J.; Festenstein, R.J. Epigenetic regulation of autosomal gene expression by sex chromosomes. Trends Genet. 2011, 27, 132-140. [CrossRef]

139. Wilson, M.A. Searching for sex differences. Science 2020, 369, 1298-1299. [CrossRef]

140. Lopes-Ramos, C.M.; Chen, C.-Y.; Kuijjer, M.L.; Paulson, J.N.; Sonawane, A.R.; Fagny, M.; Platig, J.; Glass, K.; Quackenbush, J.; DeMeo, D.L. Sex Differences in Gene Expression and Regulatory Networks across 29 Human Tissues. Cell Rep. 2020, $31,107795$. [CrossRef]

141. Oettel, A.; Lorenz, M.; Stangl, V.; Costa, S.D.; Zenclussen, A.C.; Schumacher, A. Human umbilical vein endothelial cells foster conversion of CD4+CD25-Foxp3- T cells into CD4+Foxp3+ regulatory T cells via Transforming Growth Factor-beta. Sci. Rep. 2016, 6, 23278. [CrossRef]

142. Lavoie, J.C.; Chessex, P. Gender and maturation affect glutathione status in human neonatal tissues. Free Radic. Biol. Med. 1997, 23, 648-657. [CrossRef]

143. Hartman, R.J.G.; Kapteijn, D.M.C.; Haitjema, S.; Bekker, M.N.; Mokry, M.; Pasterkamp, G.; Civelek, M.; den Ruijter, H.M. Intrinsic transcriptomic sex differences in human endothelial cells at birth and in adults are associated with coronary artery disease targets. Sci. Rep. 2020, 10, 12367. [CrossRef]

144. Montague, C.R.; Hunter, M.G.; Gavrilin, M.A.; Phillips, G.S.; Goldschmidt-Clermont, P.J.; Marsh, C.B. Activation of estrogen receptor-alpha reduces aortic smooth muscle differentiation. Circ. Res. 2006, 99, 477-484. [CrossRef] [PubMed]

145. Wu, L.; Feng, Z.; Cui, S.; Hou, K.; Tang, L.; Zhou, J.; Cai, G.; Xie, Y.; Hong, Q.; Fu, B.; et al. Rapamycin upregulates autophagy by inhibiting the mTOR-ULK1 pathway, resulting in reduced podocyte injury. PLoS ONE 2013, 8, e63799. [CrossRef] [PubMed]

146. Morey, A.K.; Pedram, A.; Razandi, M.; Prins, B.A.; Hu, R.M.; Biesiada, E.; Levin, E.R. Estrogen and progesterone inhibit vascular smooth muscle proliferation. Endocrinology 1997, 138, 3330-3339. [CrossRef] [PubMed]

147. McElreavey, K.D.; Irvine, A.I.; Ennis, K.T.; McLean, W.H. Isolation, culture and characterisation of fibroblast-like cells derived from the Wharton's jelly portion of human umbilical cord. Biochem. Soc. Trans. 1991, 19, 29S. [CrossRef] [PubMed]

148. Corotchi, M.C.; Popa, M.A.; Simionescu, M. Testosterone stimulates proliferation and preserves stemness of human adult mesenchymal stem cells and endothelial progenitor cells. Rom. J. Morphol. Embryol. 2016, 57, 75-80.

149. Mihai, M.C.; Popa, M.A.; Suica, V.I.; Antohe, F.; Jackson, E.K.; Simionescu, M.; Dubey, R.K. Mechanism of 17beta-estradiol stimulated integration of human mesenchymal stem cells in heart tissue. J. Mol. Cell Cardiol. 2019, 133, 115-124. [CrossRef] [PubMed]

150. Shi, Q.; Gao, J.; Jiang, Y.; Sun, B.; Lu, W.; Su, M.; Xu, Y.; Yang, X.; Zhang, Y. Differentiation of human umbilical cord Wharton's jelly-derived mesenchymal stem cells into endometrial cells. Stem. Cell Res. Ther. 2017, 8, 246. [CrossRef]

151. Tajiri, N.; Duncan, K.; Borlongan, M.C.; Pabon, M.; Acosta, S.; de la Pena, I.; Hernadez-Ontiveros, D.; Lozano, D.; Aguirre, D.; Reyes, S.; et al. Adult stem cell transplantation: Is gender a factor in stemness? Int. J. Mol. Sci. 2014, 15, 15225-15243. [CrossRef]

152. Maioli, M.; Contini, G.; Santaniello, S.; Bandiera, P.; Pigliaru, G.; Sanna, R.; Rinaldi, S.; Delitala, A.P.; Montella, A.; Bagella, L.; et al. Amniotic fluid stem cells morph into a cardiovascular lineage: Analysis of a chemically induced cardiac and vascular commitment. Drug. Des. Devel. Ther. 2013, 7, 1063-1073.

153. Balzano, F.; Bellu, E.; Basoli, V.; Dei Giudici, S.; Santaniello, S.; Cruciani, S.; Facchin, F.; Oggiano, A.; Capobianco, G.; Dessole, F.; et al. Lessons from human umbilical cord: Gender differences in stem cells from Wharton's jelly. Eur. J. Obstet. Gynecol. Reprod. Biol. 2019, 234, 143-148. [CrossRef]

154. Balzano, F.; Campesi, I.; Cruciani, S.; Garroni, G.; Bellu, E.; Dei Giudici, S.; Angius, A.; Oggiano, A.; Rallo, V.; Capobianco, G.; et al. Epigenetics, stem cells, and autophagy: Exploring a path involving miRNA. Int. J. Mol. Sci. 2019, 20, 5091. [CrossRef] [PubMed]

155. Gil-Kulik, P.; Swistowska, M.; Kondracka, A.; Chomik, P.; Krzyzanowski, A.; Kwasniewska, A.; Rahnama, M.; Kocki, J. Increased expression of BIRC2, BIRC3, and BIRC5 from the IAP family in mesenchymal stem cells of the umbilical cord Wharton's jelly (WJSC) in younger women giving birth naturally. Oxid. Med. Cell. Longev. 2020, 2020, 9084730. [CrossRef] [PubMed] 